\title{
Seleksi Tomatillo (Physalis ixocarpa Brot. ex Hornem) untuk Hibridisasi Berdasarkan Karakter Morfologi
}

\author{
Ermila Widyaelina ${ }^{1}$ dan Budi Waluyo ${ }^{2}$ \\ 1,2 Fakultas Pertanian Universitas Brawijaya, Malang \\ 1Email: ermilawidyaelina@gmail.com \\ Email: budiwaluyo@ub.ac.id
}

\begin{abstract}
Tomatillo (Physalis ixocarpa Brot ex. Hornem) is a species that belongs to Solanaceae family that was recently introduced in Indonesia. Tomatillo is consumed in a various preparation and has a high content of flavonoids, alkaloids, terpenes, vitamins $A$ and C. Developed of tomatillo's superior varieties from Indonesia has not been done. Tomatillo breeding needs to be done for the development of potential genotypes as the parent of newly developed superior varieties. The research purpose is to determine the variability and grouping of tomatillo genotypes based on morphological characters based on qualitative and quantitative characters. This research used 20 genotypes and arranged based on augmented design. Principal Component Analysis $(P C A)$ is used to analyze character variability. Grouping analysis was analyzed using Agglomerative Hierarchical Clustering (AHC) with similarity measures based on Pearson correlation coefficients and the Unweighted Pair Group Average (UPGMA) agglomeration method. The results showed that there was a variability between characters of $90.62 \%$ obtained from 10 main components with 27 contributing morphological characters. The 20 potential genotypes had similarity between genotypes at $89.4 \%$ and were divided into 3 groups at $96.4 \%$ similarity values. The genetic distance between the first and second groups was 0.026 , between the second and third groups was 0.032, and between the first and third groups was 0.081 . The genotypes that have the highest similarity are Pixo [P14] and Pixo [P22] and Pixo [G35] and Pixo [GY21] with 99.5\% similarity coefficient or genetic distance of 0.005 . Genotypes that have the highest variability are Pixo [P35] and Pixo [GY11] with a similarity coefficient of $81.8 \%$ or have a genetic distance of 0.182 .
\end{abstract}

Keywords: Diversity, Genetic distance, Introductive species, Qualitative and quantitative characters, Tomatillo.

\begin{abstract}
ABSTRAK
Tomatillo (Physalis ixocarpa Brot ex. Hornem) adalah spesies dari family Solanaceae yang baru diintroduksi ke indonesia. Tomatillo dikonsumsi dalam berbagai macam olahan dan memiliki kandungan flavonoid, alkaloid, terpen, vitamin A dan $\mathrm{C}$ yang tinggi. Perakitan varietas unggul tomatillo dari Indonesia belum dilakukan. Pemuliaan tanaman tomatillo perlu dilakukan untuk pengembangan genotipe potensial sebagai induk untuk pembentukan varietas unggul baru. Penelitian ini memiliki tujuan untuk menentukan keragaman karakter dan pengelompokan genotipe tomatillo berdasarkan karakter morfologi. Penelitian ini menggunakan 20 genotipe dengan rancangan acak kelompok diperluas (augmented design). Keragaman karakter dianalisis dengan Principal Component Analysis (PCA) menggunakan pendekatan koefisien korelasi Pearson, dan analisis pengelompokan menggunakan Agglomerative Hierarchical Clustering (AHC) dengan ukuran kemiripan berdasarkan koefisien korelasi Pearson dan metode aglomerasi Unweighted Pair Group Average (UPGMA). Hasil penelitian menunjukkan keragaman antar karakter sebesar $90,62 \%$ dari 10 komponen utama dengan 27 karakter morfologi yang berkontribusi. 20 genotipe potensial memiliki kemiripan antar genotipe pada nilai $89,4 \%$ dan terbagi menjadi 3 kelompok pada nilai kemiripan 96,4\%. Jarak genetik antar kelompok pertama dan kedua sebesar 0,026, antara kelompok kedua dan ketiga sebesar 0,032 , dan antara kelompok pertama dan ketiga sebesar 0,081 . Genotipe yang memiliki kemiripan paling tinggi atau jarak genetik paling dekat adalah Pixo[P14] dan Pixo[P22] serta Pixo[G35] dan Pixo[GY21 dengan nilai kemiripan $99,5 \%$ atau jarak genetik sebesar 0.005 . Genotipe yang
\end{abstract}


ISSN 2354-7251 (print)

memiliki jarak genetik terjauh yaitu Pixo[P35] dan Pixo[GY11] dengan nilai kemiripan sebesar $81,8 \%$ atau memiliki jarak genetik sebesar 0,182.

Kata kunci: Jenis introduktif, Jarak genetik, Keragaman, Sifat kualitatif dan kuantitatif, Tomatillo.

\section{Pendahuluan}

Tomatillo (Physalis ixocarpa Brot. ex Hornem) ialah tanaman dari keluarga Solanaceae yang berasal dari daerah Mesoamerika dan banyak dibudidayakan di berbagai negara. Tomatillo merupakan produk pertanian penting di negara Meksiko dan Amerika Tengah (Kindscher et al., 2012). Bagian yang bisa dikonsumsi dari tanaman tomatillo ialah buahnya. Buah tomatillo dapat dimakan dalam bentuk buah segar, bahan untuk salad, bahan baku selai sebagai hiasan makanan, dan jeli. Spesies-spesies tanaman hortikultura yang memiliki ukuran buah kecil pada umumnya memiliki senyawa fenolik, flavonoid, dan antosianin yang tinggi. Tomatillo termasuk salah satunya karena mengandung $\beta$-karoten, flavonoid, alkaloid, karotenoid, kandungan padatan terlarut dan terpena yang tinggi (Silva et al., 2016). Budidaya tomatillo tidak memerlukan perawatan khusus. Tomatillo berpotensi dikembangkan secara industri sebagai sumber antioksidan dan antikanker karena tingginya kandungan vitamin A dan Vitamin C (Desh Beer Singh et al., 2014). Buah tomatillo yang berwarna hijau umum digunakan oleh masyarakat Hispanik sebagai bahan utama pembuatan saus salsa verde menggantikan fungsi dari buah tomat karena memiliki rasa manis dan aroma yang khas atau acrid sweet (RobledoTorres et al., 2011).

Tomatillo baru diintroduksi ke Indonesia sehingga belum dikembangkan secara masif (Zanetta dan Waluyo, 2018). Masyarakat belum banyak yang mengetahui dan mengenal tanaman tomatillo. Beberapa lapisan masyarakat yang memiliki hobi bercocok tanam mulai menanam tomatillo sebagai tanaman eksotis di pekarangan rumah. Salah satu kendala dalam pengembangan tomatillo di Indonesia idalah minimnya ketersediaan genotipe lokal dan belum adanya varietas tomatillo yang berasal dari Indonesia. Benih tomatillo yang ditanam di Indonesia diimpor dari berbagai negara terutama Meksiko.

Kandungan nutrisi dan potensi lain yang dimiliki tanaman tomatillo, menjadi prospek pengembangan tomatillo di Indonesia. Perakitan varietas tomatillo yang dapat beradaptasi di Indonesia perlu dilakukan. Tahap awal yang dapat dilakukan dalam merakit varietas tomatillo adalah dengan melakukan peningkatan kapasitas genetik melalui program pemuliaan tanaman. Peningkatan kapasitas genetik dapat lebih mudah dilakukan dengan mengetahui keragaman dan jarak genetik dari koleksi genotipe tomatillo yang dimiliki. Keragaman karakter ialah variasi genetik yang terdapat di dalam satu spesies dalam suatu populasi. Jarak genetik ialah selisih genetik yang terdapat pada populasi yang masih satu spesies atau antar spesies. 
Analisis keragaman karakter tanaman dapat dilakukan melalui berbagai jenis marka, salah satunya dapat dilakukan melalui pengamatan karakter morfologi tanaman yang meliputi karakter kuantitatif dan kualitatif tanaman. Keragaman karakter tanaman selanjutnya dapat digunakan sebagai dasar pengelompokan genetik untuk mengetahui jarak genetik dari genotipe-genotipe yang diamati. Keragaman dan jarak genetik diperlukan dalam program pemuliaan tanaman tomatillo karena dapat digunakan sebagai dasar seleksi dan peningkatan kapasitas genetik untuk perakitan varietas unggul baru.

\section{Metodologi Penelitian}

Penelitian dilaksanakan pada bulan Desember 2018 sampai April 2019 yang bertempat di rumah kasa Seed and Nursery Industry Agro Techno Park Universitas Brawijaya, Desa Jatikerto Kecamatan Kromengan Kabupaten Malang. Penelitian dilakukan berdasarkan metode eksperimental yang disusun berdasarkan rancangan acak kelompok diperluas (augmented design). Pengamatan dilakukan pada karakter morfologi yang mencakup karakter kualitatif dan kuantitatif dari 20 genotipe tomatillo yang diuji dan 3 genotipe cek.

Karakter yang diamati yaitu tinggi tanaman pada percabangan pertama, panjang ruas, panjang daun, lebar daun, panjang tangkai daun, diameter bunga, jumlah kepala sari, jumlah bunga pada setiap cabang, jumlah bunga per tanaman, panjang kelopak, diameter kelopak, panjang buah, diameter buah, rasio panjang per diameter, jumlah lokul predominan, panjang tangkai buah, waktu berbunga, waktu panen, waktu masak fisiologis, jumlah buah pertanaman, bobot buah segar dengan kelopak, bobot buah per tanaman, ratarata bobot buah segar dengan kelopak, rata-rata bobot buah segar tanpa kelopak, padatan terlarut total, keasaman buah, pewarnaan antosianin pada hipokotil, tipe tumbuh, pewarnaan antosianin pada ruas, intensitas warna antosianin pada ruas, bulu ruas, bentuk daun, tepi daun, warna daun, intensitas warna hijau daun, posisi tangkai daun, posisi tangkai bunga, bentuk penampang membujur buah, bentuk penampang melintang buah, kedalaman tangkai buah, bentuk ujung buah, warna utama buah pada saat panen, intensitas warna utama buah pada saat panen, warna utama buah pada saat masak fisiologis, intesitas warna utama buah pada saat masak fisiologis, warna daging buah, kelenturan kelopak, penutupan buah oleh kelopak, bulu pada kelopak, lekukan pada kelopak, pewarnaan antosianin pada kelopak, intesitas pewarnaan antosianin pada kelopak, ketebalan pangkal tangkai buah, warna biji, ukuran buah, ukuran biji, masa simpan, ketegaran buah, dan rasio berat per volume buah.

Keragaman maksimum karakter morfologi tanaman ditentukan menggunakan principal component analysis (PCA) dengan tipe korelasi Pearson. Komponen utama yang berpengaruh pada keragaman total ditentukan dengan eigenvalue $>1$. Karakter yang 
berkontribusi terhadap keragaman maksimum pada setiap komponen ditentukan berdasarkan factor loading $>0,6$. Pengelompokan dan jarak genetik dilakukan dengan analisis klaster berdasarkan Agglomerative hierarchical clustering (AHC). Pengelompokan berdasarkan nilai kemiripan (similirity) menggunakan ukuran koefisien korelasi Pearson dan metode UPGMA (Unweighted Pair Group Method Using Arithmetic Average). Analisis dilakukan menggunakan menggunakan Microsoft Excel 2019 dan XLSTAT version 18.02.01.28451.

\section{Hasil dan Pembahasan}

\section{Keragaman karakter morfologi 20 genotipe tomatillo (Physalis ixocarpa Brot. ex Hornem)}

Analisis komponen utama (PCA) ialah analisa data menggunkan transformasi linier yang berfungsi untuk menyederhanakan data sehingga terbentuk sistem baru bervarians maksimal (Waluyo et al., 2017). Analisis komponen utama ialah analisis multivariat yang digunakan untsuk mengidentifikasi karakter tanaman yang paling berkontribusi pada variasi dalam genotipe (Verma, 2013). Analisis PCA dilakukan berdasarkan karakter kualitatif dan kuantitatif tanaman. PCA yang memiliki besaran eigenvalue $>1$ menunjukkan jumlah komponen utama, dan factor loading $>0,6$ menunjukkan karakter yang berkontribusi terhadap keragaman pada setiap komponen utama (Peres-Neto et al., 2003).

Berdasarkan hasil PCA dari karakter morfologi yang meliputi karakter kualitatif dan kuantitatif pada 20 genotipe Tomatillo didapatkan 10 komponen utama pertama yang memiliki eigenvalue $>1$ berkontribusi terhadap total keragaman sebesar 90,62\% (Tabel 1). Hal ini menunjukkan keragaman karakter tanaman yang tinggi (Lal et al., 2017). Berdasarkan analisa komponen utama karakter morfologi mempunyai nilai kontribusi terhadap keragaman menunjukkan nilai yang berbeda, sehingga karakter yang berkontribusi terhadap keragaman maksimum turut berbeda.

Berdasarkan factor loading $>0,6$, terdapat 27 karakter yang berpengaruh terhadap keragaman total. Principal Component 1 (PC1) dengan eigenvalue 12,241 berkontribusi terhadap keragaman maksimum sebesar 27,20\% yaitu karakter jumlah bunga per tanaman, diameter kelopak, panjang buah, diameter buah, rata-rata bobot buah segar dengan kelopak, rata-rata bobot buah segar tanpa kelopak, intensitas warna antosianin pada ruas (Gambar 1), warna utama buah pada saat panen (Gambar 2), warna utama buah pada saat masak fisiologis (Gambar 3), intensitas warna utama buah pada saat masak fisiologis (Gambar 4), warna daging buah (Gambar 5), dan pewarnaan antosianin pada kelopak (Gambar 6). 
Tabel 1. Eigenvalue, Keragaman, keragaman kumulatif, dan factor loading 20 genotipe Tomatillo berdasarkan karakter kualitatif dan kuantitatif.

\begin{tabular}{|c|c|c|c|c|c|c|c|c|c|c|}
\hline Komponen dan karakter tanaman & PC1 & PC2 & PC3 & PC4 & PC5 & PC6 & PC7 & PC8 & PC9 & PC10 \\
\hline Tinggi tanaman pada percabangan pertama $(\mathrm{cm})$ & -0.143 & 0.371 & -0.269 & 0.225 & 0.387 & 0.108 & $0.717^{*}$ & 0.026 & 0.003 & 0.110 \\
\hline Panjang Ruas $(\mathrm{cm})$ & 0.168 & -0.494 & -0.456 & -0.066 & 0.377 & -0.068 & 0.522 & 0.062 & -0.089 & 0.003 \\
\hline Panjang daun (cm) & 0.512 & 0.236 & 0.518 & 0.024 & 0.279 & 0.240 & 0.224 & 0.326 & -0.147 & 0.031 \\
\hline Lebar daun $(\mathrm{cm})$ & 0.379 & 0.113 & 0.596 & 0.259 & 0.205 & 0.362 & 0.246 & 0.203 & -0.133 & 0.160 \\
\hline Panjang tangkai daun (cm) & 0.189 & $0.718^{*}$ & 0.111 & 0.105 & 0.232 & -0.187 & -0.070 & -0.142 & 0.376 & 0.094 \\
\hline Diameter bunga $(\mathrm{cm})$ & 0.431 & 0.038 & 0.579 & 0.221 & -0.270 & 0.293 & -0.093 & 0.081 & 0.054 & 0.105 \\
\hline Jumlah kepala sari & 0.000 & 0.000 & 0.000 & 0.000 & 0.000 & 0.000 & 0.000 & 0.000 & 0.000 & 0.000 \\
\hline Jumlah bunga pada setiap cabang & 0.000 & 0.000 & 0.000 & 0.000 & 0.000 & 0.000 & 0.000 & 0.000 & 0.000 & 0.000 \\
\hline Jumlah bunga per tanaman & $0.838^{*}$ & -0.304 & -0.147 & -0.075 & 0.128 & 0.129 & 0.186 & 0.035 & -0.019 & -0.204 \\
\hline Panjang kelopak (cm) & 0.509 & 0.199 & -0.276 & -0.105 & 0.163 & -0.049 & -0.392 & 0.342 & -0.465 & -0.237 \\
\hline Diameter kelopak (cm) & $0.659^{*}$ & $0.689^{*}$ & -0.153 & -0.016 & -0.039 & -0.076 & -0.007 & 0.013 & -0.040 & 0.014 \\
\hline Panjang buah (cm) & $0.663^{*}$ & 0.578 & -0.268 & -0.209 & 0.043 & -0.153 & 0.011 & -0.143 & 0.055 & -0.072 \\
\hline Diameter buah (cm) & $0.714^{*}$ & $0.607^{*}$ & -0.235 & -0.129 & 0.090 & 0.015 & 0.000 & -0.085 & 0.081 & -0.016 \\
\hline Rasio panjang/diameter & 0.248 & 0.198 & 0.270 & -0.255 & 0.565 & -0.245 & -0.085 & 0.045 & 0.480 & -0.057 \\
\hline Jumlah lokul predominan & 0.444 & -0.005 & -0.239 & -0.232 & 0.535 & 0.299 & -0.094 & 0.351 & 0.135 & 0.237 \\
\hline Panjang tangkai buah (cm) & 0.378 & 0.445 & -0.241 & -0.022 & 0.030 & -0.313 & -0.295 & 0.580 & -0.025 & 0.149 \\
\hline Waktu berbunga (HST) & 0.071 & -0.137 & -0.470 & $0.738^{*}$ & 0.231 & 0.131 & -0.222 & 0.095 & -0.041 & -0.039 \\
\hline Rata-rata bobot buah segar dengan kelopak (g) & $0.818^{*}$ & 0.392 & -0.190 & -0.101 & -0.217 & -0.099 & 0.109 & -0.033 & -0.088 & -0.022 \\
\hline Rata-rata bobot buah segar tanpa kelopak (g) & $0.776^{*}$ & 0.423 & -0.222 & -0.101 & -0.248 & -0.111 & 0.107 & -0.056 & -0.072 & -0.011 \\
\hline Padatan terlarut total (\%) & -0.459 & -0.428 & -0.183 & -0.350 & 0.446 & 0.124 & 0.226 & 0.032 & -0.192 & 0.038 \\
\hline Keasaman buah & -0.007 & 0.235 & 0.105 & 0.094 & 0.313 & $0.811^{*}$ & -0.203 & 0.072 & -0.131 & -0.092 \\
\hline Pewarnaan antosianin pada hipokotil & 0.000 & 0.000 & 0.000 & 0.000 & 0.000 & 0.000 & 0.000 & 0.000 & 0.000 & 0.000 \\
\hline Tipe tumbuh & 0.000 & 0.000 & 0.000 & 0.000 & 0.000 & 0.000 & 0.000 & 0.000 & 0.000 & 0.000 \\
\hline Pewarnaan antosianin pada ruas & 0.000 & 0.000 & 0.000 & 0.000 & 0.000 & 0.000 & 0.000 & 0.000 & 0.000 & 0.000 \\
\hline
\end{tabular}




\begin{tabular}{|c|c|c|c|c|c|c|c|c|c|c|}
\hline Komponen dan karakter tanaman & PC1 & PC2 & PC3 & PC4 & PC5 & PC6 & PC7 & PC8 & PC9 & PC10 \\
\hline Intensitas warna antosianin pada ruas & $-0.764^{*}$ & 0.460 & -0.057 & 0.181 & -0.121 & -0.208 & 0.071 & 0.060 & -0.152 & 0.034 \\
\hline Bulu ruas & 0.000 & 0.000 & 0.000 & 0.000 & 0.000 & 0.000 & 0.000 & 0.000 & 0.000 & 0.000 \\
\hline Bentuk daun & 0.000 & 0.000 & 0.000 & 0.000 & 0.000 & 0.000 & 0.000 & 0.000 & 0.000 & 0.000 \\
\hline Tepi daun & 0.229 & -0.170 & -0.425 & $0.737^{\star}$ & 0.165 & -0.014 & -0.048 & -0.154 & 0.144 & 0.058 \\
\hline Warna daun & 0.000 & 0.000 & 0.000 & 0.000 & 0.000 & 0.000 & 0.000 & 0.000 & 0.000 & 0.000 \\
\hline Intensitas warna hijau daun & 0.000 & 0.000 & 0.000 & 0.000 & 0.000 & 0.000 & 0.000 & 0.000 & 0.000 & 0.000 \\
\hline Posisi tangkai daun & -0.050 & -0.331 & $-0.654^{*}$ & 0.500 & 0.252 & -0.122 & -0.116 & -0.079 & -0.227 & 0.135 \\
\hline Posisi tangkai bunga & -0.498 & -0.237 & 0.092 & -0.290 & -0.408 & -0.220 & 0.243 & 0.062 & -0.456 & -0.098 \\
\hline Bentuk penampang membujur buah & -0.244 & -0.306 & -0.069 & -0.458 & 0.346 & -0.571 & 0.102 & 0.268 & -0.109 & 0.028 \\
\hline Bentuk penampang melintang buah & 0.000 & 0.000 & 0.000 & 0.000 & 0.000 & 0.000 & 0.000 & 0.000 & 0.000 & 0.000 \\
\hline Kedalaman tangkai buah & -0.171 & -0.057 & -0.404 & -0.555 & -0.435 & 0.490 & 0.025 & 0.125 & 0.078 & -0.046 \\
\hline Bentuk ujung buah & 0.000 & 0.000 & 0.000 & 0.000 & 0.000 & 0.000 & 0.000 & 0.000 & 0.000 & 0.000 \\
\hline Warna utama buah pada saat panen & $-0.762^{*}$ & 0.432 & 0.174 & -0.104 & 0.150 & -0.072 & -0.100 & -0.044 & -0.011 & 0.023 \\
\hline Intensitas warna utama buah pada saat panen & -0.183 & -0.591 & -0.380 & 0.231 & -0.468 & 0.228 & -0.010 & 0.128 & 0.175 & 0.165 \\
\hline Warna utama buah pada saat masak fisiologis & $-0.652^{*}$ & 0.576 & -0.113 & -0.149 & 0.048 & 0.138 & 0.069 & 0.122 & 0.206 & -0.234 \\
\hline Intesitas warna utama buah pada saat masak fisiologis & $-0.649^{*}$ & 0.591 & -0.175 & 0.262 & 0.021 & 0.091 & -0.018 & 0.150 & 0.023 & -0.199 \\
\hline Warna daging buah & $-0.710^{*}$ & 0.587 & 0.092 & -0.005 & 0.062 & 0.060 & 0.126 & 0.004 & -0.036 & -0.158 \\
\hline Kelenturan kelopak & -0.275 & 0.416 & -0.258 & -0.043 & 0.389 & 0.145 & -0.332 & -0.386 & -0.337 & -0.003 \\
\hline Penutupan buah oleh kelopak & 0.478 & 0.214 & 0.404 & 0.277 & -0.444 & 0.019 & 0.096 & 0.319 & 0.009 & -0.200 \\
\hline Bulu pada kelopak & 0.000 & 0.000 & 0.000 & 0.000 & 0.000 & 0.000 & 0.000 & 0.000 & 0.000 & 0.000 \\
\hline Lekukan pada kelopak & -0.194 & -0.178 & 0.367 & $0.713^{*}$ & 0.255 & -0.171 & -0.061 & 0.119 & -0.105 & -0.297 \\
\hline Pewarnaan antosianin pada kelopak & $-0.602^{*}$ & 0.363 & -0.313 & 0.244 & -0.421 & -0.085 & 0.038 & 0.074 & -0.005 & 0.118 \\
\hline Intesitas pewarnaan antosianin pada kelopak & -0.526 & 0.538 & -0.233 & 0.248 & -0.301 & 0.035 & 0.195 & 0.154 & 0.108 & 0.137 \\
\hline Ketebalan pangkal tangkai buah & 0.000 & 0.000 & 0.000 & 0.000 & 0.000 & 0.000 & 0.000 & 0.000 & 0.000 & 0.000 \\
\hline Warna biji & 0.000 & 0.000 & 0.000 & 0.000 & 0.000 & 0.000 & 0.000 & 0.000 & 0.000 & 0.000 \\
\hline Ukuran buah & 0.577 & 0.260 & 0.022 & -0.179 & -0.147 & 0.030 & -0.129 & -0.042 & -0.239 & $0.600^{*}$ \\
\hline Ukuran biji & 0.497 & -0.116 & $0.671^{*}$ & 0.197 & -0.028 & -0.060 & 0.005 & -0.292 & -0.266 & 0.117 \\
\hline Masa simpan & 0.527 & $-0.603^{\star}$ & -0.337 & 0.135 & -0.281 & 0.148 & 0.059 & 0.088 & 0.134 & -0.034 \\
\hline Ketegaran buah & 0.592 & -0.363 & -0.171 & 0.159 & -0.227 & -0.145 & -0.063 & 0.221 & 0.069 & -0.118 \\
\hline Rasio berat/volume buah & 0.145 & 0.277 & 0.181 & 0.630 & 0.032 & -0.534 & 0.216 & 0.076 & -0.049 & 0.119 \\
\hline Eigenvalue & 12.241 & 8.251 & 4.303 & 3.945 & 3.359 & 2.777 & 1.822 & 1.520 & 1.458 & 1.102 \\
\hline Variability (\%) & 27.202 & 18.335 & 9.562 & 8.767 & 7.465 & 6.172 & 4.049 & 3.377 & 3.241 & 2.450 \\
\hline Cumulative \% & 27.202 & 45.538 & 55.100 & 63.867 & 71.331 & 77.503 & 81.552 & 84.929 & 88.170 & 90.620 \\
\hline
\end{tabular}

Keterangan: *) Karakter kuantitatif yang berkontribusi sebagai komponen utama pada keragaman maksimum. 

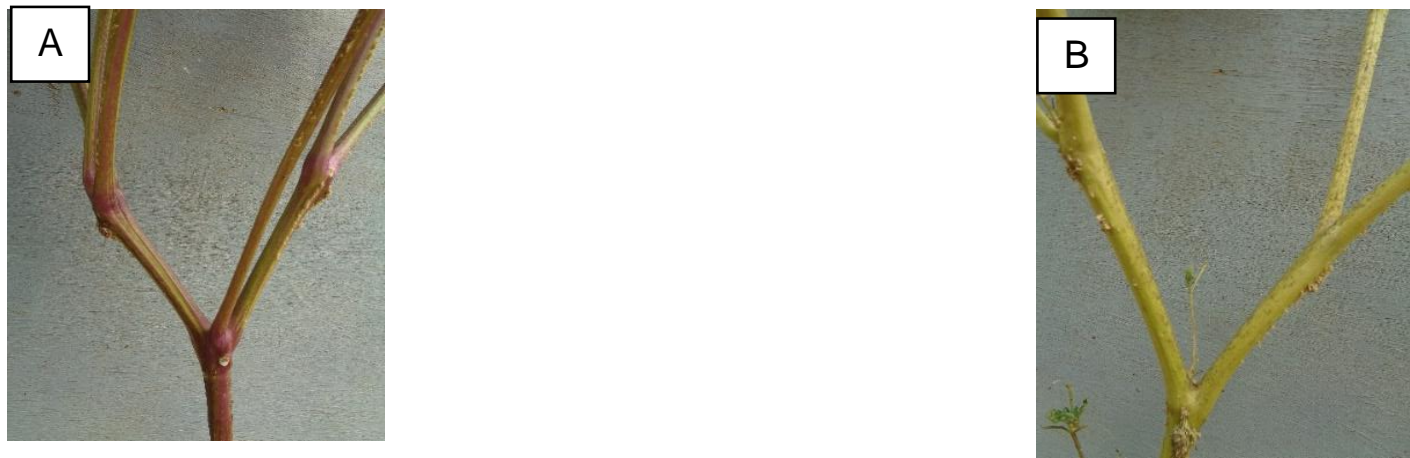

Gambar 1. Intensitas pewarnaan antosianin pada ruas dari 20 genotipe tanaman tomatillo $(P$. ixocarpa Brot. ex Hornem) menunjukkan intensitas (A); kuat dan (B); lemah.
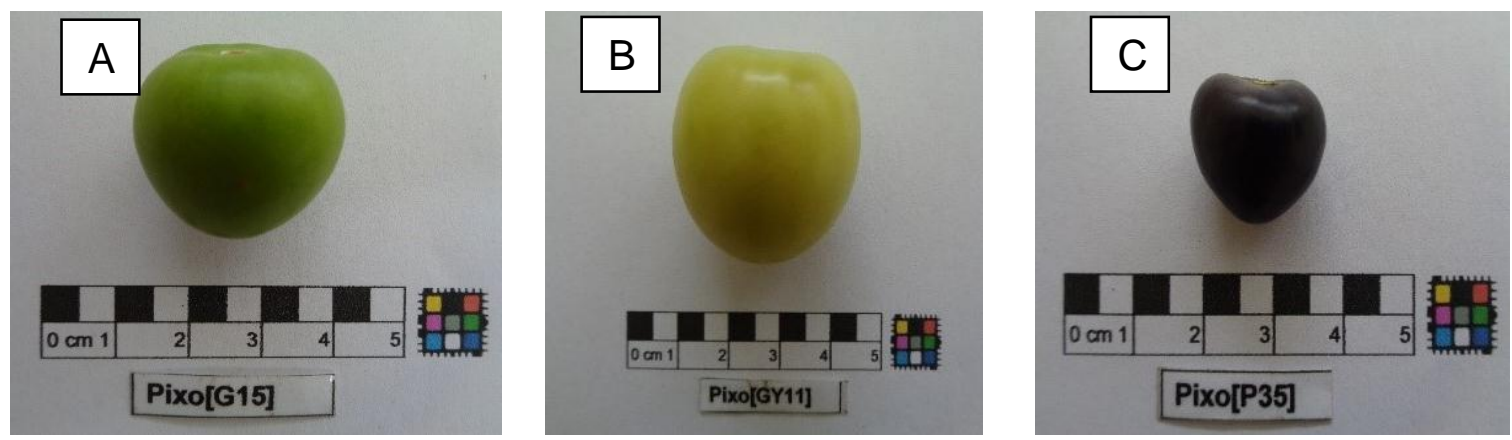

Gambar 2. Warna utama buah dari 20 genotipe tanaman tomatillo ( $P$. ixocarpa Brot. ex.Hornem) pada saat masak fisiologis yaitu (A); hijau, (B); kuning, dan (C); ungu.
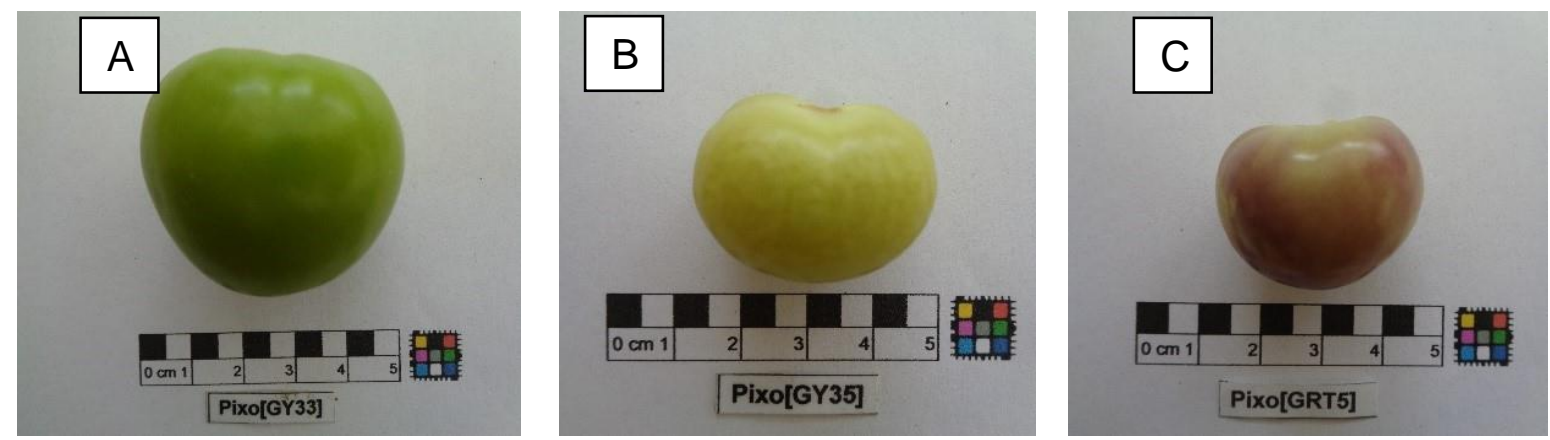

Gambar 3. Warna utama buah dari 20 genotipe tanaman tomatillo ( $P$. ixocarpa Brot. ex Hornem) pada saat panen yaitu (A); hijau, (B); kuning, dan (C); ungu
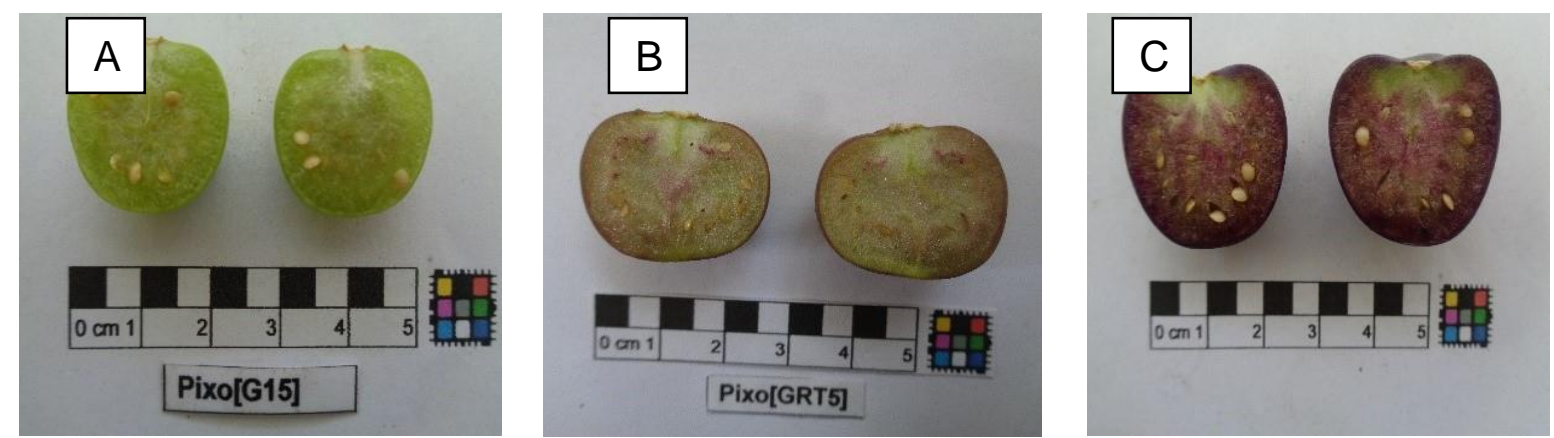

Gambar 4. Warna daging buah dari 20 genotipe tanaman tomatillo ( $P$. ixocarpa Brot. ex Hornem) yaitu (A); hijau, (B); hijau keunguan, dan (C); ungu. 

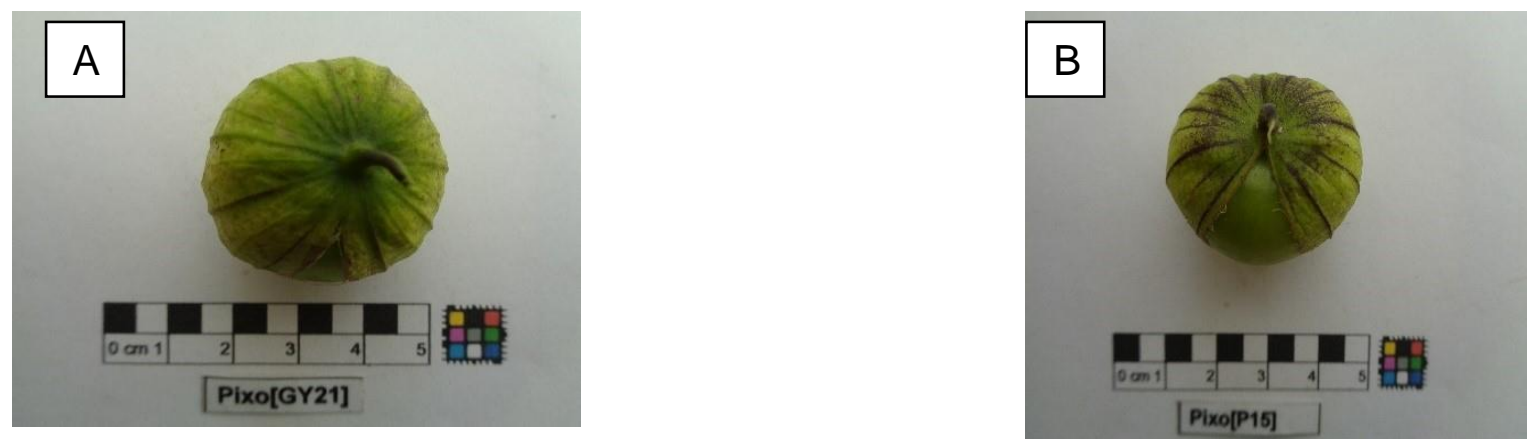

Gambar 5. Pewarnaan antosianin pada kelopak buah 20 genotipe tanaman tomatillo $(P$. ixocarpa Brot. ex Hornem) menunjukkan (A); tidak adanya pewarnaan antosianin pada kelopak buah dan (B); terdapat pewarnaan antosianin pada kelopak buah.
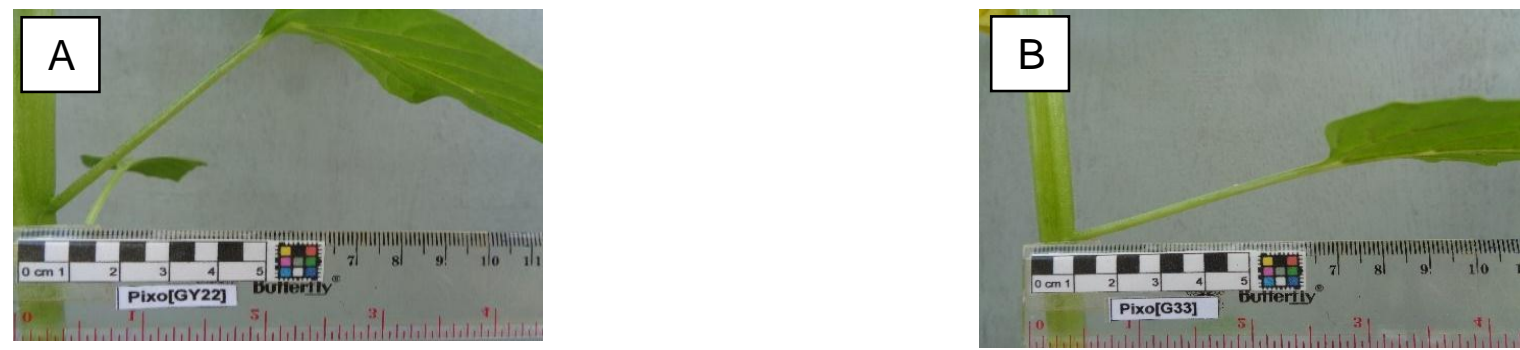

Gambar 6. Posisi tangkai daun yang terdapat pada 20 genotipe tanaman tomatillo ( $P$. ixocarpa Brot. ex Hornem) menunjukkan (A); posisi tangkai daun tegak dan (B); posisi tangkai daun semi tegak
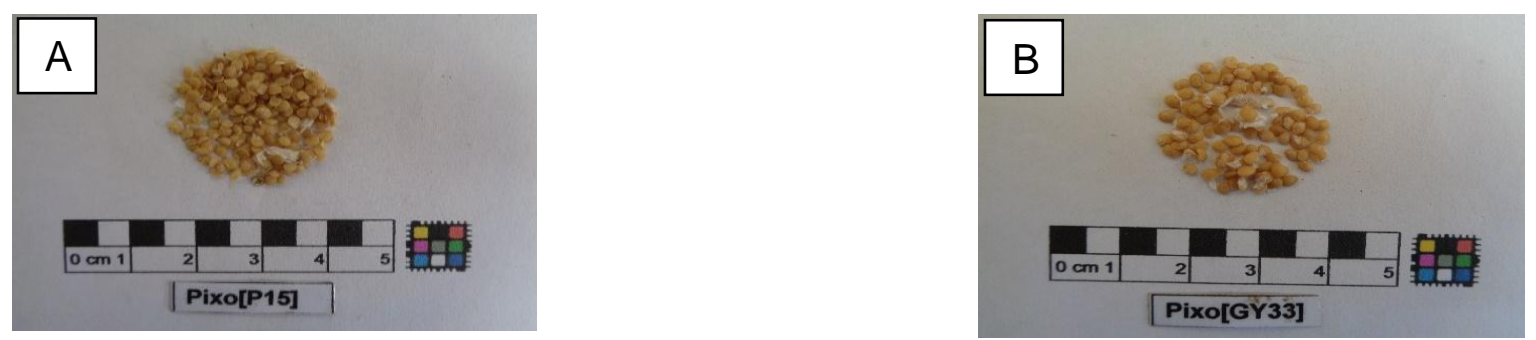

Gambar 7. Ukuran biji pada 20 genotipe tanaman tomatillo ( $P$. ixocarpa Brot. ex Hornem) berkisar antara (A); biji berukuran besar dan (B); biji dengan ukuran kecil.

PC2 dengan eigenvalue sebesar 8,251 berkontribusi terhadap maksimum sebesar 18,34\% terkait karakter panjang tangkai daun, diameter kelopak, diameter buah, dan masa simpan. PC3 mempunyai eigenvalue sebesar 4,303 dan berkontribusi terhadap keragaman maksimum sebesar 9,56\% terkait karakter posisi tangkai daun (Gambar 6) dan ukurun biji (Gambar 7)

PC4 mempunyai eigenvalue sebesar 3,945 dan berkontribusi terhadap keragaman maksimum sebesar $8,77 \%$. Karakter yang berkontribusi terhadap keragaman pada PC4 ialah waktu berbunga, tepi daun (Gambar 8), dan lekukan pada kelopak (Gambar 9). PC5 mempunyai eigenvalue sebesar 3,359 dan berkontribusi terhadap keragaman maksimum sebesar 7,47\%. PC6 memiliki eigenvalue sebesar 2,777 dan berkontribusi terhadap keragaman maksimum sebesar $6,17 \%$ terkait keasaman buah. PC7 bernilai eigenvalue 
sebesar 1,822 dan berkontribusi terhadap keragaman maksimum sebesar 4,05\% terkait karakter tinggi tanaman pada percabangan pertama. PC8 mempunyai eigenvalue sebesar 1,520 dan memberikan kontribusi terhadap keragaman maksimum sebesar 3,38\%. PC9 mempunyai eigenvalue sebesar 1,458 dan memberikan kontribusi terhadap keragaman maksimum sebesar 3,24\%. PC10 bernilai eigenvalue sebesar 1,102 dan berkontribusi terhadap keragaman maksimum sebesar 2,45\% terkait karakter ukuran buah (Gambar 10).
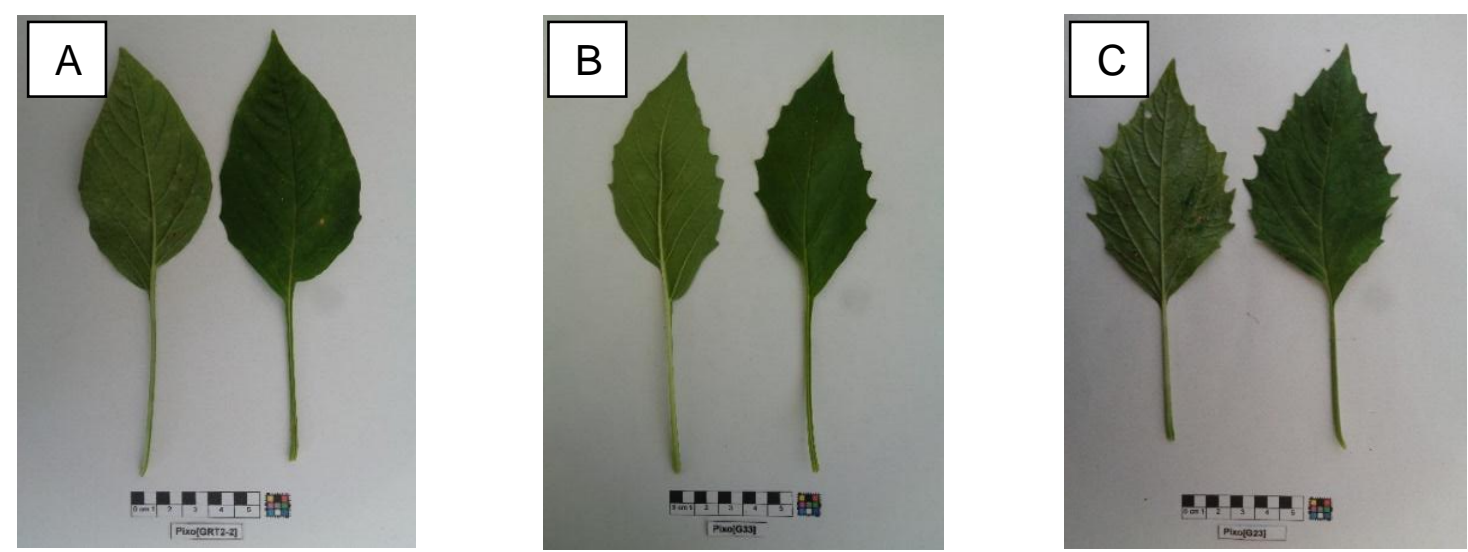

Gambar 8. Tepi daun pada 20 genotipe tanaman tomatillo ( $P$. ixocarpa Brot. ex Hornem) menunjukkan $(A)$; lekukan yang lemah, $(B)$; lekukan yang medium, dan $(C)$; lekukan yang kuat.
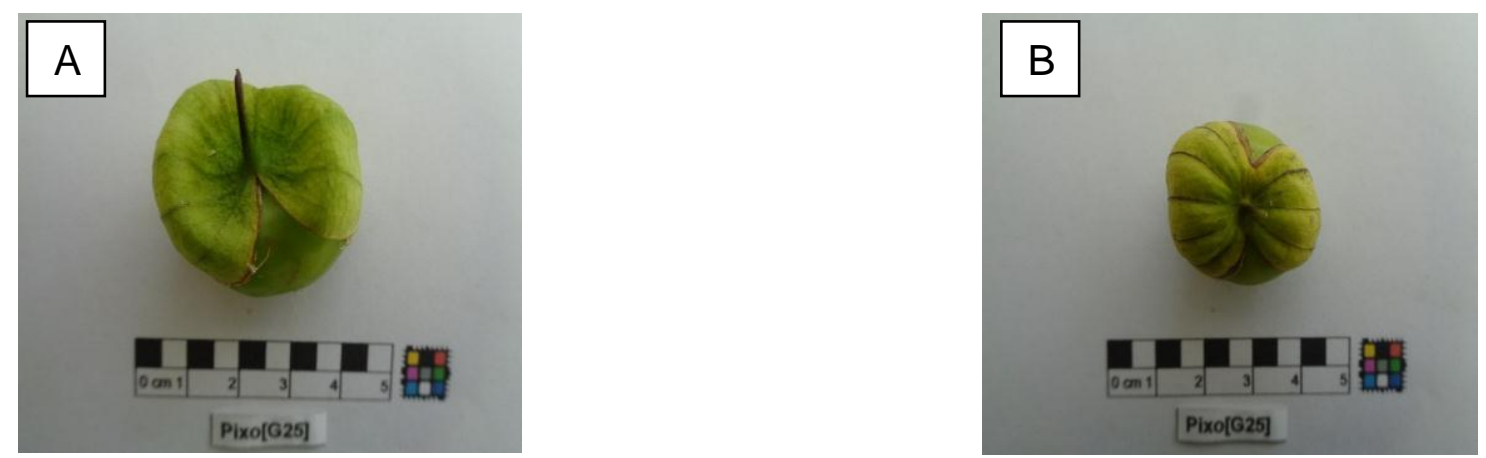

Gambar 9. Lekukan kelopak yang terdapat pada 20 genotipe tanaman tomatillo ( $P$. ixocarpa Brot. ex Hornem) menunjukkan (A); tidak adanya lekukan pada kelopak, dan (B); adanya lekukan pada kelopak.
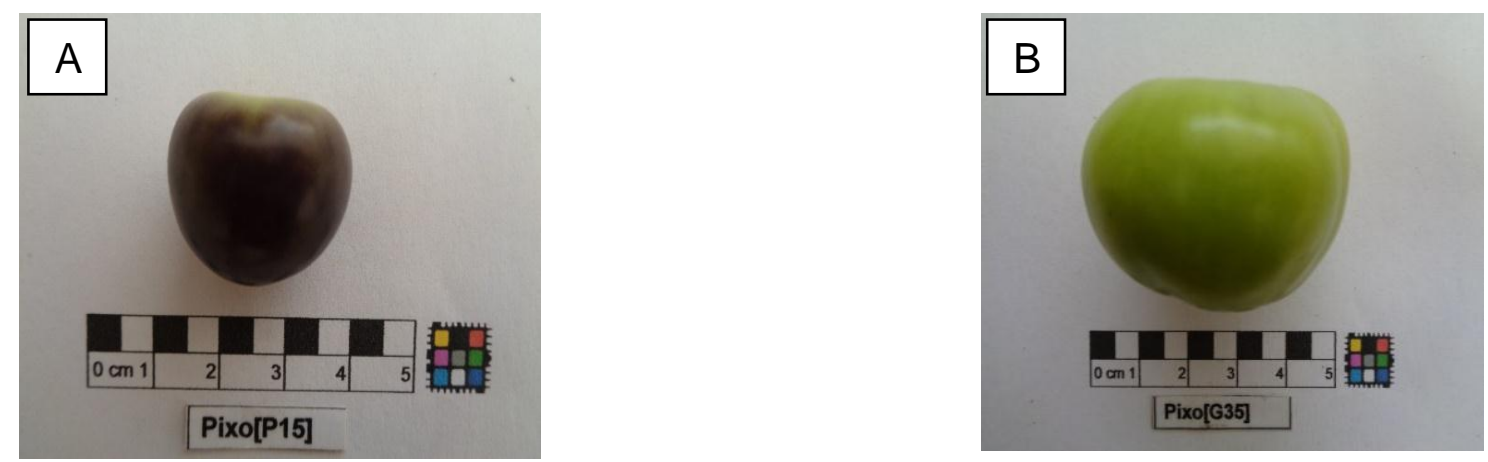

Gambar 10. Ukuran buah pada 20 genotipe tanaman tomatillo ( $P$. ixocarpa Brot. ex Hornem) berkisar antara $(A)$; buah dengan ukuran medium, dan (B); buah berukuran besar. 
Hasil penelitian mengenai keragaman karakter morfologi pada 20 genotipe tomatillo sesuai dengan penelitian sebelumnya yang dilakukan oleh Freyre et al. (2000) yaitu keragaman karakter terdapat pada jumlah buah, berat buah total, dan rata-rata berat buah per tanaman. Karakter morfologi lain yang beragam sesuai dengan penelitian Bermejo and León (1994) yaitu ukuran buah dan warna buah, dan Singh et al. (2013) yaitu keragaman teridentifikasi pada waktu berbunga dan berbuah, jumlah bunga, lebar buah, panjang buah, panjang kelopak buah, panjang tangkai buah, dan waktu masak panen.

\section{Pengelompokan dan Jarak Genetik 20 Genotipe Tomatillo (Physalis ixocarpa Brot. ex Hornem)}

Analisis jarak genetik berdasarkan analisis pengelompokan digunakan untuk menentukan jauh dekatnya jarak genetik dari 20 genotipe tomatillo yang diamati. Analisis pengelompokan jarak genetik dilakukan berdasarkan koefisien korelasi Pearson menggunakan metode aglomerasi unweighted pair-group methode using arithmatic average (UPGMA). Korelasi Pearson ialah korelasi sederhana yang berguna untuk menstandardisasi data yang akan dianalisis, sehingga dapat menentukan kelompok yang menghubungkan antar sifat dari masing-masing pasangan karakter. Jarak genetik dianalisis menggunakan analisis kelompok. Analisis kelompok berfungsi untuk memperkuat analisis PCA dan mengetahui jarak genetik dari genotipe-genotipe yang diuji dalam bentuk dendrogram (Wei et al., 2012). Analisis kelompok digunakan untuk mengidentifikasi kelompok genotipe berdasarkan karakter tanaman.

Berdasarkan hasil analisis kelompok, seluruh genotipe menjadi satu kelompok pada koefisien kemiripan $89,4 \%$ dan terbagi menjadi tiga kelompok utama pada koefisien kemiripan 96,4\%. Hal ini menunjukkan bahwa 20 genotipe tomatillo memiliki kemiripan antar genotipe sebesar $89,4 \%$ atau 0,894 dan mulai berbeda pada tingkat kemiripan $96,4 \%$ atau 0,964. Kelompok yang berbeda berguna untuk mengetahui kesamaan hubungan jarak genetik antar genotipe. Genotipe dalam satu kelompok yang sama, memiliki jarak genetik yang dekat ditandai dengan banyaknya kesamaan yang dimiliki, genotipe dalam kelompok yang berbeda menunjukkan jarak genetik yang jauh yang ditandai dengan kesamaan yang lebih sedikit. Pembagian kelompok pada analisis ini didasarkan pada kesamaan masing-masing genotipe dilihat dari koefisien kemiripan. Semakin kecil nilai koefisien kemiripan genetik atau semakin besar jarak genetik maka tingkat kemiripan semakin kecil dan sebaliknya (Garzón-Martínez et al., 2015). Nilai kemiripan yang diperoleh semakin tinggi maka nilai jarak genetik semakin dekat. 


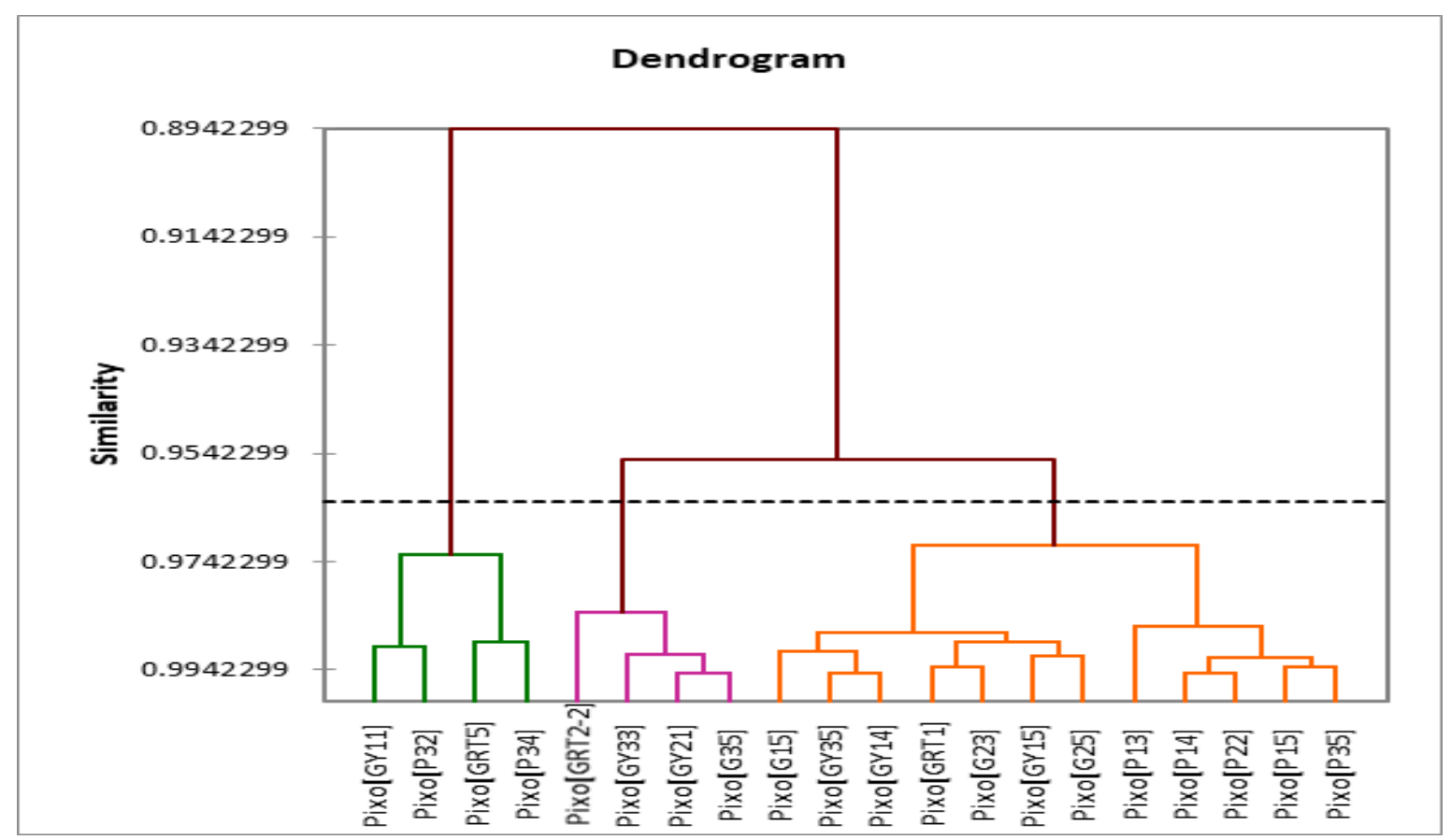

Gambar 11. Dendrogram 20 genotipe tomatillo yang terbagi menjadi tiga kelompok berdasarkan kesamaan karakter morfologi yang mencakup karakter kualitatif dan kuantitatif.

Jarak genetik antar kelompok pertama, kedua, dan ketiga berbeda. Jarak genetik kelompok pertama dan kedua sebesar 0,026. Jarak genetik antara kelompok kedua dan ketiga sebesar 0,032. Kelompok pertama dan ketiga memiliki jarak genetik yang lebih jauh dengan nilai 0,081 . Hal ini menunjukkan bahwa kelompok pertama lebih dekat dengan kelompok kedua dibandingkan dengan kelompok ketiga. Semakin jauh jarak genetik antar kelompok maka semakin berbeda karakter morofologi yang terdapat pada genotipe tersebut.

Kelompok pertama yang mengelompok pada koefisien 97,4\% terdiri dari 12 genotipe dengan 11 kesamaan karakter morfologi. Karakter yang sama pada kelompok ini adalah rasio panjang per diameter, waktu panen, waktu masak fisiologis, padatan terlarut total, posisi tangkai daun, posisi tangkai bunga, bentuk penampang membujur buah, warna utama buah pada saat panen, intensitas warna utama buah pada saat panen, dan lekukan pada kelopak. Genotipe yang memiliki jarak genetik dekat pada kelompok pertama adalah Pixo[P14] dan Pixo[P22] yaitu sebesar 0,005. Genotipe dengan jarak genetik terjauh pada kelompok pertama ialah Pixo[P13] dan Pixo[GY35] dengan jarak genetik sebesar 0,051. Pada kelompok pertama genotipe yang memiliki kesamaan karakter morfologi paling banyak adalah Pixo[P14] dan Pixo[P22] karena memiliki jarak genetik paling dekat, sedangkan Pixo[P13] dan Pixo[GY35] memiliki kesamaan yang paling rendah pada kelompok pertama karena memiliki jarak genetik tejauh. 
Kelompok kedua yang mengelompok pada koefisien 98,4\% terdiri dari 4 genotipe yaitu Pixo[GY33], Pixo[GY21], Pixo[G35], dan Pixo[GRT2-2]. Genotipe-genotipe ini mengelompok dengan kesamaan karakter panjang daun, lebar daun, diameter bunga, jumlah bunga per tanaman, jumlah lokul predominan, waktu berbunga, keasaman buah, kedalaman tangkai buah, intensitas warna utama buah pada saat panen, penutupan buah oleh kelopak, ukuran biji, masa simpan, ketegaran buah, dan rasio berat/volume buah. Genotipe yang memiliki jarak genetik Paling dekat pada kelompok kedua adalah Pixo[G35] dan Pixo[GY21] dengan jarak genetik sebesar 0,005. Genotipe dengan jarak genetik paling jauh ialah Pixo[GY21] dan Pixo[GRT2-2] dengan jarak genetik sebesar 0.019 .

Kelompok ketiga yang mengelompok pada koefisien 97,4\% terdiri dari 4 genotipe yaitu Pixo[GRT5], Pixo[GY11], Pixo[P32], dan Pixo[P34]. Kesamaan karakter yang didapatkan pada kelompok ketiga yaitu tinggi tanaman pada percabangan pertama, panjang tangkai daun, panjang kelopak, diameter kelopak, panjang buah, diameter buah, rasio panjang/diameter, panjang tangkai buah, jumlah buah pertanaman, bobot buah segar dengan kelopak, bobot buah per tanaman, rata-rata bobot buah segar dengan kelopak, rata-rata bobot buah segar tanpa kelopak, intensitas warna antosianin pada ruas, warna utama buah pada saat panen, warna utama buah pada saat masak fisiologis, intesitas warna utama buah pada saat masak fisiologis, warna daging buah, kelenturan kelopak, penutupan buah oleh kelopak, pewarnaan antosianin pada kelopak, intesitas pewarnaan antosianin pada kelopak, ukuran buah, dan ukuran biji.

Genotipe yang memiliki jarak genetik paling dekat pada kelompok ketiga adalah Pixo[P32] dan Pixo[GY11] dengan jarak genetik sebesar 0,01. Genotipe dengan jarak genetik paling jauh ialah Pixo[P34] dan Pixo[GY11] dengan jarak genetik sebesar 0,047. Genotipe yang memiliki kemiripan paling tinggi atau jarak genetik paling dekat adalah Pixo[P14] dan Pixo[P22] serta Pixo[G35] dan Pixo[GY21]. Kedua pasang genotipe tersebut memiliki nilai kemiripan $99,5 \%$ atau jarak genetik sebesar 0.005 . Genotipe yang memiliki jarak genetik terjauh yaitu Pixo[P35] dan Pixo[GY11] dengan nilai kemiripan sebesar $81,8 \%$ atau memiliki jarak genetik sebesar 0,182.

Keseluruhan karakter morfologi meliputi karakter kualitatif dan kuantitatif pada 20 genotipe tomatillo menunjukkan nilai koefisien kemiripan terbesar berkisar antara 89,4\%$99,5 \%$. Hal ini mengindikasikan bahwa keragaman antar genotipe pada 20 genotipe tomatillo termasuk rendah. Dendrogram jarak genetik memberikan informasi bahwa semakin rendah nilai kemiripan maka perbedaan semakin tinggi dan mengindikasikan keragaman antar genotipe, sehingga jarak genetik yang terbentuk memiliki nilai yang tinggi, begitu pula sebaliknya. Analisis kemiripan karakter antar genotipe berguna untuk 
menafsirkan jarak genetik secara akurat. Genotipe yang memiliki jarak genetik dekat mengindikasikan kemiripan karakter morfololgi yang dapat digunakan untuk meningkatkan ekspresi suatu sifat, sedangkan genotipe yang memiliki jarak genetik jauh mengindikasikan adanya perbedaan karakter morfololgi yang dapat digunakan untuk meningkatkan keragaman pada populasi melalui hibridisasi sehingga meningkatkan efisiensi perancangan genotipe baru (Trevisani et al., 2016).

\section{Kesimpulan}

Keragaman total antar karakter tanaman pada 20 genotipe tomatillo tergolong tinggi yaitu sebesar 90,62\%. Terdapat 10 komponen utama dan 27 karakter morfologi yang berpengaruh terhadap keragaman total meliputi ruas, daun, bunga, kelopak dan buah. Keragaman antar genotipe tomatillo tergolong rendah karena memiliki koefisien kemiripan 89,4\%-99,5\%. Jarak genetik antara tiga kelompok tomatillo menunjukkan nilai yang berbeda. Jarak genetik antara kelompok pertama dan kedua sebesar 0,026, antara kelompok kedua dan ketiga sebesar 0,032, dan antara kelompok pertama dan ketiga memiliki jarak genetik sebesar 0,081. Genotipe yang memiliki jarak genetik paling jauh ialah Pixo[P35] dan Pixo[GY11] dengan jarak genetik sebesar 0,182, sedangkan genotipe yang memiliki kemiripan paling tinggi atau jarak genetik paling dekat adalah Pixo[P14] dan Pixo[P22] serta Pixo[G35] dan Pixo[GY21] dengan jarak genetik sebesar 0.005. Genotipegenotipe yang memiliki jarak genetik jauh dapat digunakan untuk meningkatkan keragaman dalam populasi melalui hibridisasi.

\section{Daftar Pustaka}

Freyre, R., Loy, J. B., \& Five, S. U. (2000). Variety trials. HortTechnology, 10(2), 0-3.

Garzón-Martínez, G. A., Osorio-Guarín, J. A., Delgadillo-Durán, P., Mayorga, F., EncisoRodríguez, F. E., Landsman, D., \& Barrero, L. S. (2015). Genetic diversity and population structure in Physalis peruviana and related taxa based on InDels and SNPs derived from COSII and IRG markers. Plant Gene, 4, 29-37. https://doi.org/10.1016/J.PLGENE.2015.09.003

Hernándo Bermejo J.E and León J. (1994). Tomatillo, husk-tomato. In Neglected crops from a different perspective. (Plant Prot, pp. 117-122). Rome, Italy: FAO.

Kindscher, K., Long, Q., Corbett, S., Bosnak, K., Loring, H., Cohen, M., \& Timmermann, B. N. (2012). The ethnobotany and ethnopharmacology of wild tomatillos, Physalis longifolia Nutt., and related Physalis species: a review. Economic Botany, 66(3), 298-310. https://doi.org/10.1007/s12231-012-9210-7

Lal, S., Singh, D., Sharma, O., Rather, S., \& Qureshi, I. (2017). Assessment of genetic variability among antioxidant constituents in Husk tomato (Physalis ixocarpa Brot.) selections grown in temperate region. Journal of Pharmacognosy and Phytochemistry JPP, 6(66), 1188-1193. Retrieved from http://www.phytojournal.com/archives/2017/vol6issue6/PartQ/6-6-12-966.pdf

Peres-Neto, P. R., Jackson, D. A., \& Somers, K. M. (2003). Giving meaningful 
interpretation to ordination axes: assessing loading significance in principal component analysis. Ecology, 84(9), 2347-2363. https://doi.org/10.1890/00-0634

Robledo-Torres, V., Ramírez-Godina, F., Foroughbakhch-Pournavab, R., BenavidesMendoza, A., Hernández-Guzmán, G., Humberto Reyes-Valdés, M., \& ReyesValdés, M. H. (2011). Development of tomatillo (Physalis ixocarpa Brot.) autotetraploids and their chromosome and phenotypic characterization. Breeding Science, 61(3), 288-293. https://doi.org/10.1270/jsbbs.61.288

Silva, D. F., Pio, R., Soares, J. D. R., Elias, H. H. D. S., Villa, F., \& Vilas Boas, E. V. D. B. (2016). Light spectrum on the quality of fruits of physalis species in subtropical area. Bragantia, 75(3), 371-376. https://doi.org/10.1590/1678-4499.463

Singh, D B, Ahmed, N., Mirza, A., Lal, S., \& Pal, A. A. (2013). Introduction , characterisation and evaluation of Husk Tomato ( Physalis ixocarpa Brot .) genotypes under temperate climate. Indian J.Plant Genet. Resour, 26(3), 226-230.

Singh, Desh Beer, Ahmed, N., Lal, S., Mirza, A., Sharma, O. C., \& Pal, A. A. (2014). Variation in growth, production and quality attributes of Physalis species under temperate ecosystem. Fruits, 69(1), 31-40. https://doi.org/10.1051/fruits/2013099

Trevisani, N., Schmit, R., Beck, M., Guidolin, A. F., Luís, J., \& Coimbra, M. (2016). Selection of fisalis population for hibriditation, based on fruit traits. Rev.Bras.Frutic, 38(2), 568. https://doi.org/10.1590/0100-29452016568

Verma, M. K. (2013). Character association and path analysis in hip rose (Rosa sp .) genotypes collected from north western himalayan region of kashmir. African Journal of Agricultural Research, 8(39), 4949-4955. https://doi.org/10.5897/AJAR2013.6950

Waluyo, B., Ramayanti, F., \& Saptadi, D. (2017). Keragaman genetik karakteristik fisik biji jarak kepyar (Ricinus communis L .) lokal untuk bahan baku industri. In Seminar Nasional Pembangunan Pertanian II (pp. 317-321).

Wei, J., Hu, X., Yang, J., \& Yang, W. (2012). Identification of single-copy orthologous genes between Physalis and Solanum lycopersicum and analysis of genetic diversity in Physalis using molecular markers. PloS One, 7(11), e50164. https://doi.org/10.1371/journal.pone.0050164

Zanetta, C. U., \& Waluyo, B. (2018). The Character variability and genetic divergence of tomatillo (Physalis ixocarpa Brot .) as a selection base for the increasing of genetic capacity of exotic fruits. https://doi.org/10.13140/RG.2.2.11837.10726/2 